\title{
Isolation and Characterization of a Novel Triolein Selective Lipase from Soil Environmental Genes
}

\author{
Hee Kyung Lim', Ye-Jin Han ${ }^{1}$, Moon-Sun Hahm², Soo Youl Park', and In Taek Hwang ${ }^{1 *}$ \\ ${ }^{1}$ Korea Research Institute of Chemical Technology, Daejeon 34114, Republic of Korea \\ ${ }^{2}$ Bioprogen, VentureTown Jangyoungsil, Daejeon 34324, Republic of Korea
}

Received: July 16, 2020 / Revised: August 19, 2020 / Accepted: September 15, 2020

\begin{abstract}
A novel lipase gene, Lip-1420, was isolated from a metagenomic library constructed from reed marsh from Mt. Jumbong in Korea, comprising 112,500 members of recombinant plasmids. The DNA sequence of Lip1420 -subclone $(5,513 \mathrm{bp})$ was found to contain at least 11 ORFs according to the GenBank database. The ORF-3 gene was inserted into the pET21a plasmid containing the C-terminal 6-His tag and transformed into $E$. coli BL21(DE3) to express the recombinant lipase protein. Lip-1420 was purified using a fast protein liquid chromatography system. The gene was registered in GenBank (MH628529). The values of $K_{m}$ and $V_{\text {max }}$ were determined as $0.268 \mathrm{mM}$ and 1.821 units, respectively, at $40^{\circ} \mathrm{C}$ and $\mathrm{pH} 8.0$, using $p$-nitrophenyl palmitate as the substrate. This lipase belongs to family IV taxonomically because it has conserved HGGG and GDSAG motifs in the constitutive amino acid sequence. According to the predicted structural model, the binding sites are represented by residues H78, G81, D150, S151, A152, V181, and D236. Finally, Lip-1420 showed triolein selectivity for methanolysis between triolein (18:1) and tristearin (18:0) substrates. Further study of the selective mechanism and structure-function relationship of this new lipase could be useful for more practical applications.
\end{abstract}

Keywords: Lipase, rhizosphere, metagenomics, 3D-structure, triolein selectivity

\section{Introduction}

Lipase (EC 3.1.1.3) is an enzyme that catalyzes the hydrolysis and synthesis of long-chain acyl glycerol and is an important industrial biocatalyst group that has been used for a long time in various fields such as organic chemistry, pharmaceuticals, foods and leather industries [1]. It is also well known for its excellent ability to perform a variety of chemical, regio and enantio selective modifications [2]. Lipase has received worldwide attention by organic chemists due to general ease of handling, broad substrate resistance, high stability to temperature and solvents, and convenient commercial availability. Lipase also plays a major role in the produc-

\section{*Corresponding author}

Tel: +82-42-860-7447, Fax: +82-42-860-7437

E-mail: ithwang@krict.re.kr

() 2020, The Korean Society for Microbiology and Biotechnology tion of biodiesel from bio-oils using the esterification of free fatty acids [3].

In response to diverse industry developments, the discovery of a new lipase will continue to be required and will increase the multiplicity of enzymes to meet new tasks. The source of most lipase enzyme development has been found from environment, such as plants, animals and microorganisms (fungi, bacteria, yeast, etc.). Therefore, most known lipases are used in many productions in the food, detergent, pharmaceutical, leather, textile, cosmetics and paper industries as they are bacteriological, naturally friendly, non-toxic and free of harmful residues.

However, it is well known that more than $99 \%$ of microorganisms cannot be explored because only $0.1-1 \%$ of the many microorganisms in nature can be grown [4, 5]; thus, metagenomics has become a progressively significant option for finding new enzymes from micro- 
organism complex. Which is defined as genomic or functional analysis of bacterial communities that do not require cultivation [6]. As a result, metagenomics technology has enhanced the discovery practice of new biocatalysts by directly exploit the full range of natural microbial residents [7-10]. Lee et al. [8] proved that planted soils are a great metagenomic resource for the development of new lipolytic enzymes.

Currently, in the lipase industry, it is required not only to produce a new lipase but also to develop a new catalyst for industrial production. For example, medicinal industry and biodiesel production need lipase which is stable in water-compatible organic solvents, and lipophilic lipase isolated from the aquatic environment is useful in a variety of industries as break down the oily stain from cloth [11]. In particular, detergent lipases should have high activity and stability at a wide range of temperatures and $\mathrm{pHs}$, and should be compatible with other components of detergents including metal ions, surfactants and oxidants [12]. Industries that require new lipases include the dairy and pharmaceutical industry [13], detergents and surfactants [14], flavor or perfume industry [15], and pesticide industries [14]. Particularly, lipase that can produce biodiesel through a transesterification process is also required [16]. The advantage of using lipase in the production of biodiesel is that it can catalyze the reaction under relatively low temperature and glycerol can be recovered easily from biodiesel [3]. However, most bio-oils are currently being used as biodiesel fuel as a method of indiscriminately converting fatty acid esters. However, if it can be used as a long-chain chemical raw material through the selective conversion of unsaturated fatty acids, the added value will be greatly improved.

This paper is a series of studies to develop and utilize new lipase through the isolation, sequencing, replication, expression, overexpression, enzyme purification, and prediction of 3D structure etc. If a new enzyme can be used to selectively modify the saturated or unsaturated fatty acids that make up the bio-oil, the application area can be dramatically increased.

\section{Materials and Methods}

\section{Biomaterials and chemicals}

Strain of Escherichia coli (E. coli) EPI-100 was culti- vated in Luria-Bertani (LB) agar plate supplemented with suitable antibiotics at $37^{\circ} \mathrm{C}$. The types and concentrations of antibiotics used were chloramphenicol $(50 \mu \mathrm{g} /$ $\mathrm{ml})$, ampicillin $(100 \mu \mathrm{g} / \mathrm{ml})$, and kanamycin $(50 \mu \mathrm{g} / \mathrm{ml})$. pEpiFOS-5 plasmids (Epicenter, USA) and pUC119 vector were used to make 112,500 metagemomic library and genes encoding lipolysis enzymes were carefully chosen and sub cloned.

\section{Metagenomics library construction}

Metagenomic libraries were constructed using soil samples collected from Shinsong-ri, Chungnam and Mt. Jumbong in Gangwon province in Republic of Korea. Five $\mathrm{g}$ of soil sample, air-dried and passed through a $1.4 \mathrm{~mm}$ diameter mesh, was placed in buffer $(15 \mathrm{ml}$, $100 \mathrm{mM}$ Tris-HCl, $\mathrm{pH}$ 8.0) solution. Soil DNA isolation and purification were performed according to the previously reported method [17, 18], and a total of 112,500 clones in the $E$. coli metagenomic library were cryotubes (with over 500 clones) and stored in a $-80^{\circ} \mathrm{C}$ deep freezer.

\section{Selection gene and DNA cloning}

Lipolytic enzymes were screened using Luria-Bertani (LB) agar media emulsified with $1 \%$ tributyrin [18]. Metagenomic clones were inoculated on LB agar plates and incubated at $37^{\circ} \mathrm{C}$ for $2-4$ days. Hydrolysis of tributyrin was determined by the appearance of clear halo zone around the colonies on LB agar plates. Selected clones were digested with restriction enzyme BamHI and finally confirmed lipolytic active clones by electrophoresis. Plasmid DNA was digested with PstI to make several 2-5 kb DNA fragments and ligated to pUC119 [19] to produce a second shotgun library. Lipase active subclones were prepared by plating the prepared library on LB agar plates supplemented with ampicillin and tributyrin and incubating at $37^{\circ} \mathrm{C}$ for 2 days.

\section{Lipase Lip-1420 overexpression} 5'-GCGACAGGCCATATGAGTCAGATTCCGGCTGA$3^{\prime}$ and 5'-GCGTCAGGACTCGAGGTGTTTGAGATGTTTGTCG-3' were used as a primers and a restriction enzyme recognition site for NdeI was added. The Plasmid pET21a (+)-ORF3-6H (Fig. 1) was amplified by polymerase chain reaction (PCR) under the following conditions, $20 \mu \mathrm{l}$ of $5 \times$ PCR buffer solution, $10 \mu \mathrm{l}$ of Nsolution, $2 \mu \mathrm{l}$ of each primer (100 pmole), $1 \mu \mathrm{l}$ of template 


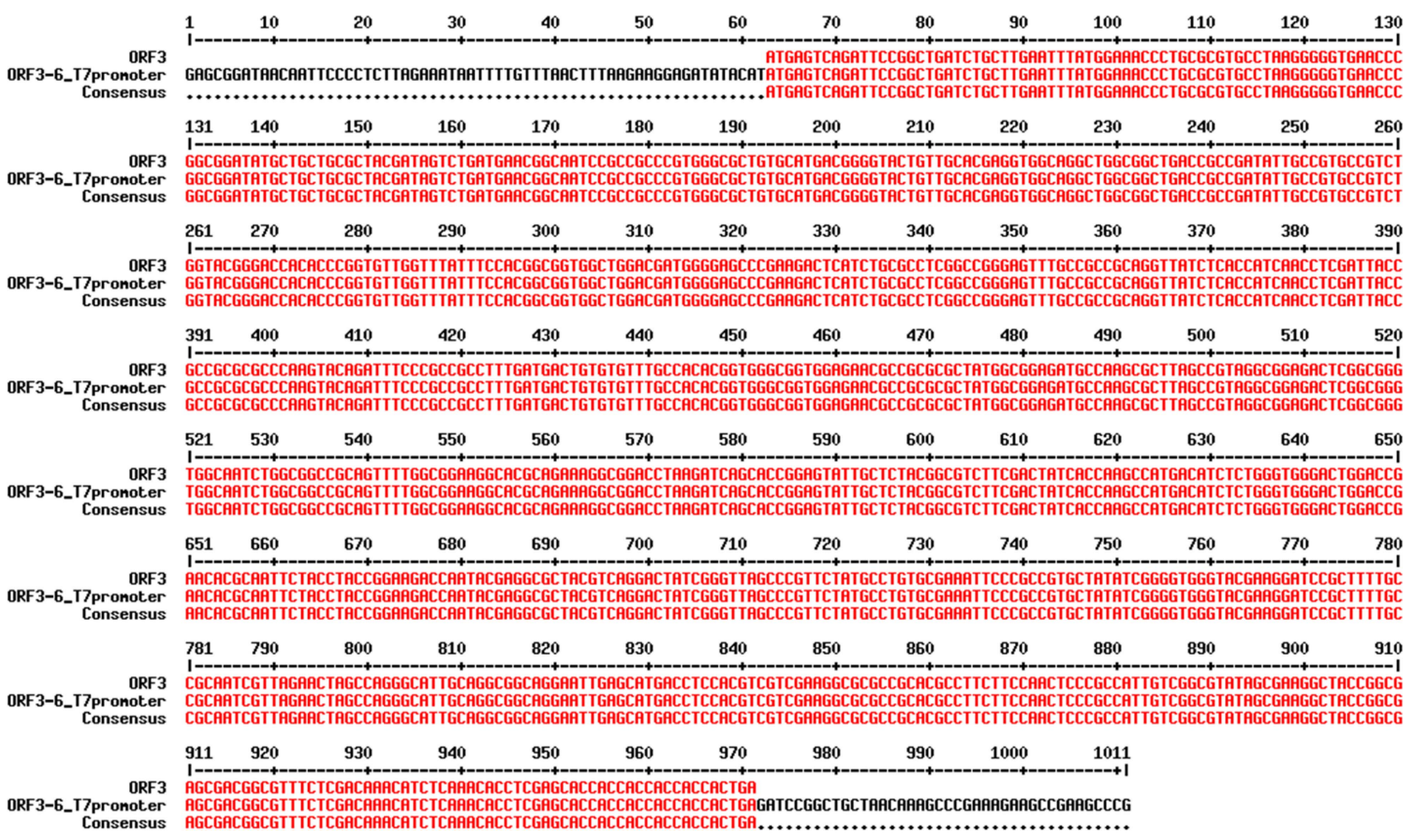

Fig. 1. Sequencing comparison for pET21a + ORF3-6H expression using T7 promoter.

DNA, $1 \mu \mathrm{l}$ of pfu DNA polymerase and $64 \mu \mathrm{l}$ of sterilized water for a final volume of $100 \mu \mathrm{l}$. The amplification performed in a thermal Cycler (Bio-Rad, USA) was as follows: 30 cycles of $95^{\circ} \mathrm{C}$ for $30 \mathrm{sec}, 58^{\circ} \mathrm{C}$ for $30 \mathrm{sec}$ and $72^{\circ} \mathrm{C}$ for $40 \mathrm{sec}$. The amplified PCR products were analyzed by $1.5 \%(\mathrm{w} / \mathrm{v})$ agarose gel electrophoresis and purified with a PCR purification kit (Bioneer Co., Korea). The fragments were sequenced and introduced into pET21a(+) digested with $N d e \mathrm{I}-\mathrm{XhoI}$, and the resulting plasmid was named pET21a(+)-Lip1420-6H. To increase the solubility of the target protein, the plasmid pET21a (+)-MBP (or GST)-lipase was generated by overlap extension PCR of MBP (or GST) gene and lipase gene [20].

\section{Lipase Lip-1420 production}

Plasmids were transformed into the expression host $E$. coli BL21 (DE3) (F-omp T hsdSB (rB-mB-) gal dcm (DE3)) (Stratagene, USA) and plated on LB plates. A single colony was taken and grown in $100 \mathrm{ml}$ of LB agar plate containing $100 \mu \mathrm{g} / \mathrm{ml}$ ampicillin at $37^{\circ} \mathrm{C}$ until $\mathrm{OD}_{600}$ was 0.6 , and inoculated $5,000 \mathrm{ml}$ of $\mathrm{LB}$ with ampicillin. D-thiogalactopyranoside (IPTG, GibcoBRL, USA) was added at a final concentration of $1 \mathrm{mM}$ and further cultured at $20^{\circ} \mathrm{C}$ for $16 \mathrm{~h}$. The cultured cells were harvested by centrifugation at $6,000 \times g$ for $10 \mathrm{~min}$ at $4^{\circ} \mathrm{C}$ and washed three times with $10 \mathrm{ml}$ of ice-cold wash buffer (50 mM Tris-HCl and $1 \mathrm{mM}$ EDTA, $\mathrm{pH}$ 8.0). And then suspended in a dissolution buffer $(50 \mathrm{mM}$ Tris- $\mathrm{HCl}$ and $200 \mathrm{mM} \mathrm{NaCl}, \mathrm{pH}$ 7.0). Collected $E$. coli was suspended in lysis buffer $(50 \mathrm{mM}$ Tris- $\mathrm{HCl}$ and $200 \mathrm{mM} \mathrm{NaCl}$, $\mathrm{pH}$ 7.0) and disrupted by ultrasonication using a sonic destructor (CosmoBio Co., Ltd.). Cell debris was removed by centrifugation at $12,000 \times \mathrm{g}$ for $30 \mathrm{~min}$ at $4{ }^{\circ} \mathrm{C}$ and the harvested proteins were subjected to SDS-polyacrylamide gel electrophoresis according to the method of Laemmli [21].

Specifically, Ni-NTA (nickel-nitrilotriacetic acid, Qiagen, Germany) was added to a chromatography column (bed volume, $20 \mathrm{ml}$, Millipore, USA) to saturate the column with nickel ions, and a $50 \mathrm{mM}$ nickel solution in the form of sulfate was added to remove unbound metal ions. After adding a solution containing the separated lipase protein to the column, washing the column with a buffer solution (50 mM Tris-HCl, 0.15 M sodium chlo- 

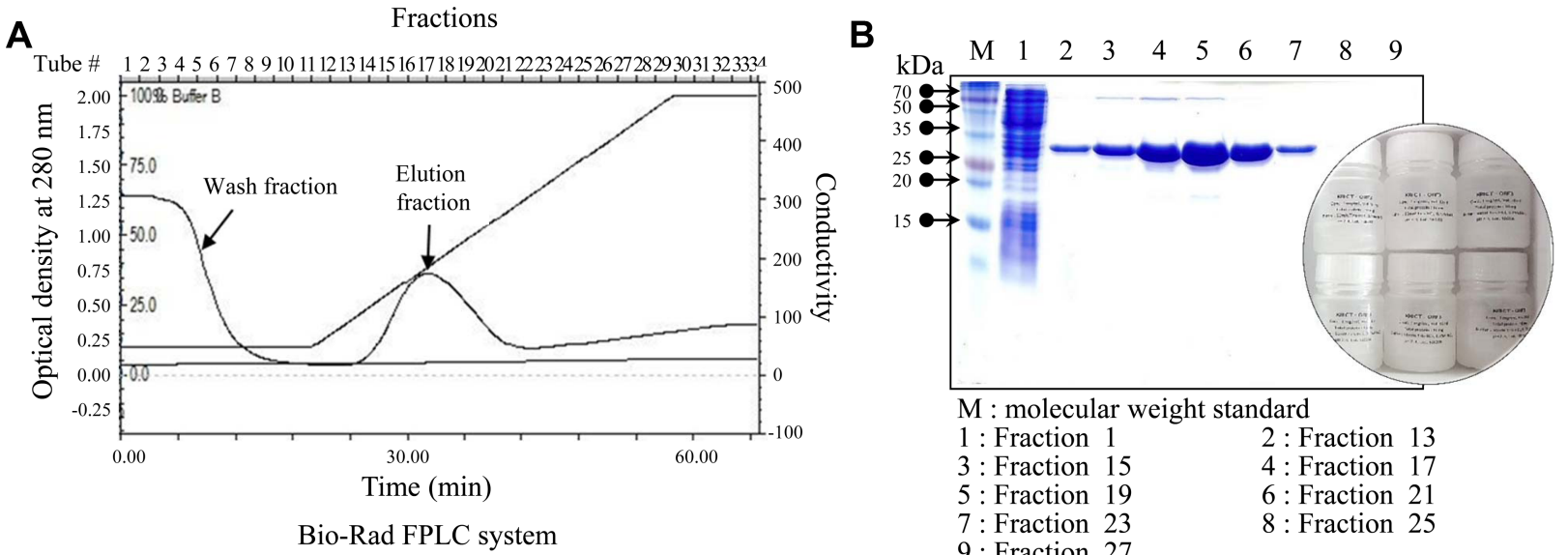

Fig. 2. FPLC system for enzyme harvesting (A) and SDS-PAGE analysis (B). Column chromatography: Bio-rad HR system, Column $(2 \times 30 \mathrm{~cm}$, Millipore, USA), Resin (Ni-NTA, QIAGEN, Germany), Bed volume $20 \mathrm{ml}$, Flow rate $4 \mathrm{ml} / \mathrm{min}$, Sample $400 \mathrm{ml}$; SDS-PAGE analysis system: Hoefer minigel, Acrylamide gel 15\%, $1 \mathrm{~mm}$ thickness, $120 \mathrm{~V}$ constant current, $1.5 \mathrm{~h}$, Coomassie Brilliant Blue staining, Sample loading $20 \mu \mathrm{l}$. The final lipase production was $1 \mathrm{mg} / \mathrm{ml}$ in buffer solution ( $50 \mathrm{mM}$ Tris- $\mathrm{HCl}, 0.15 \mathrm{M} \mathrm{NaCl}, \mathrm{pH} 7.4)$.

ride, $\mathrm{pH}$ 7.4), a continuous imidazole gradient was placed and the buffer. The solution was passed through and purified by fast protein liquid chromatography (FPLC) (Fig. 2A), and purified lipase protein was obtained as each fraction. Using each fraction, electrophoresis was performed in the same manner as described in Example 72 , and it was confirmed that a $34 \mathrm{kDa}$ lipase protein was present (Fig. 2B). The lipase protein mass produced as described above was diluted to a concentration of $1 \mathrm{mg} /$ $\mathrm{ml}$ in the buffer solution, placed in a container, and stored at $-70^{\circ} \mathrm{C}$.

Lipase Lip1420 was purified using Bio-rad HR system FPLC (flow rate of $4 \mathrm{ml} / \mathrm{min}$ and sample volume of $400 \mathrm{ml}$, Bioprogen, Korea). Ni-NTA (nickel-nitrilotriacetic acid, Qiagen) was added to a chromatography column (total volume, $20 \mathrm{ml}$, Millipore) to saturate the column with nickel ions. Subsequently, a $50 \mathrm{mM}$ nickel solution in the form of sulfate was added to remove unbound metal ions. After adding a solution containing the lipase protein separated by the column, washing the column

Table 1. Information of Lip-1420-sub gene consisting open reading frames (ORF) from GeneBank.

\begin{tabular}{|c|c|c|c|c|}
\hline ORF & $\begin{array}{l}\text { Length } \\
\text { (bp/aa) }\end{array}$ & Description & Strain (ID\%) & Accession \\
\hline ORF1 & $1590 / 529$ & Protein of unknown function & Thiocapsa roseopersicina (48\%) & SDW97003.1 \\
\hline ORF2 & $1236 / 411$ & LLM class flavin-dependent oxidoreductase & Blastopirellula marina (50\%) & WP_002655372.1 \\
\hline ORF3 & $885 / 294$ & esterase/lipase protein & uncultured organism (78\%) & AFQ30768.1 \\
\hline ORF4 & $825 / 274$ & alpha/beta hydrolase & Pseudorhodoplanes sinuspersici (37\%) & WP_086087576.1 \\
\hline ORF5 & $495 / 164$ & $\begin{array}{l}\text { PREDICTED:3-hydroxyisobutyryl-CoA hydrolase, } \\
\text { mitochondrial-like }\end{array}$ & Polistes dominula (26\%) & XP_015178720.1 \\
\hline ORF6 & $435 / 144$ & 4-methyl-5-beta-hydroxyethyl thiazole kinase & $\begin{array}{l}\text { Listeria welshimeri serovar 6b str. } \\
\text { SLCC5334(35\%) }\end{array}$ & AOAFC3.1 \\
\hline ORF7 & $423 / 140$ & No significant similarity found & & \\
\hline ORF8 & $402 / 133$ & RNA-directed RNA polymerase & Pseudomonas virus phi6(42\%) & P11124.3 \\
\hline ORF9 & $327 / 108$ & $\begin{array}{l}\text { Phosphoribosylformylglycinamidine synthase } \\
\text { subunit PurL }\end{array}$ & Leifsonia xyli subsp. xyli str. СТСВ07(31\%) & Q6ACC3.1 \\
\hline ORF10 & 294/97 & PEP12 homolog & Arabidopsis thaliana (67\%) & Q39233.1 \\
\hline ORF11 & $237 / 78$ & No significant similarity found & & \\
\hline
\end{tabular}


with a buffer solution (50 mM Tris- $\mathrm{HCl}, 0.15 \mathrm{M}$ sodium chloride, $\mathrm{pH}$ 7.4), the buffer solution was placed in a continuous imidazole gradient. By passing through, a purified lipase protein was obtained. The lipase protein mass produced as described above was diluted to a concentration of $1 \mathrm{mg} / \mathrm{ml}$ in the buffer solution, placed in a container, and stored at $-70^{\circ} \mathrm{C}$ (Fig. 4). SDS-polyacrylamide gel electrophoresis (SDS-PAGE) was carried out under conditions of Hoefer mini gel (15\% acrylamide gel of $1 \mathrm{~mm}$ thickness, $20 \mu \mathrm{l}$ sample loading, and constant current of $120 \mathrm{~V}, 1.5 \mathrm{~h}$ run time). After mixing the protein with Laemmli sample buffer, SDS-PAGE was performed and stained with Coomassie Brilliant Blue R250 to confirm the presence of a $34 \mathrm{kDa}$ lipase protein.

\section{Enzyme activity and biochemical characterization}

The enzymatic activity of the recombinant Lip1420 was evaluated by $P$-nitrophenyl palmitate $(p-\mathrm{NPP})$ assay. In the $P$-NPP assay, $25 \mu \mathrm{l}$ of $3 \mathrm{mM} p$-NPP solution as a substrate, $5 \mu \mathrm{g}$ of purified enzyme and $200 \mu \mathrm{l}$ of $50 \mathrm{mM}$ glycine- $\mathrm{NaOH}$ buffer ( $\mathrm{pH} 8.0$ ) were added to the tube and incubated in a heating block at $40^{\circ} \mathrm{C}$ for $10 \mathrm{~min}$. The amount of $p$-nitrophenol ( $p$-NP) was measured by absorbance at $410 \mathrm{~nm}$ with a spectrophotometer. Activity was calculated by replacing the measured values with a $p$ $\mathrm{NP}$ standard curve. One micromole of $p$-NP released in one minute per $\mathrm{mg}$ of protein is defined as a unit of esterase activity (U) [13]. The optimal temperature and $\mathrm{pH}$ conditions were determined by irradiating the esterase activity of the recombinant proteins at various temperatures $\left(20\right.$ to $70^{\circ} \mathrm{C}$ ) and $\mathrm{pH}$ conditions ( $\mathrm{pH} 2$ to 12) on a 96-well microplate. The kinetic parameters (HanesWoolf constant $K_{\mathrm{m}}$ and maximal reaction velocity $V_{\max }$ ) were estimated by linear regression from double-reciprocal plots.

\section{D structure modeling of the lipase Lip-1420}

Nucleotide and deduced amino acid sequences were analyzed with CLC Free Workbench, Ver. 3.2.1 (CLC bio A/S, www.clcbio.com). Related sequences were obtained from database searches (SwissPort and GenBank). The secondary structure of Lip-1420 was predicted by using LOMETS (a local meta-threading-server for protein structure prediction) server [22]. A 3D model was obtained by the hierarchical protein structure modeling approach based on secondary-structure enhanced Pro-
file-Profile threading Alignment (PPA) and the iterative implementation of the TASSER (Threading ASSEmbly Refinement) program [23]. Suggesting the ligand binding site of the target protein through COFACTOR (structure comparison and protein-protein network use) and $\mathrm{COACH}$ (which combines the functions of several programs). Among the proposed binding sites, binding sites were formed based on the ligands of PAF-AH (Platelet-activating factor acetyl hydrolase, pdb id: 3D5E) with the highest $\mathrm{C}$ score (reliability score to estimate the quality of the predicted model).

\section{Triolein selective alcoholysis}

Enzyme Lip-1420 was added to $2 \mathrm{ml}$ vial containing $50 \mu \mathrm{g}$ of protein and freeze-dried. Then, $20 \mathrm{ml}$ of $18: 0$ or 18:1 tri-glyceride (Purity> 99\%) dissolved in methyl alcohol was added to each vial in $500 \mu \mathrm{l}$ aliquots (Total volume of $1.5 \mathrm{ml}$ ). The reaction mixture was reacted at $40^{\circ} \mathrm{C}$ in a shaking incubator (200 rpm), $1 \mathrm{ml}$ of dimethyl chloride was added at 0,24 and $96 \mathrm{~h}$, and the reaction was terminated. The production of free fatty acid methyl ester was analyzed by gas chromatography (GC). GC analysis was performed on Agilent Technologies 7820A with DB-1HT column $(30 \mathrm{~m} \times 0.32 \mathrm{~mm} \times 0.1 \mathrm{~m})$. Oven temperature was held at $40^{\circ} \mathrm{C}$ for $1 \mathrm{~min}$ and then programmed to $350^{\circ} \mathrm{C}$ for $28.167 \mathrm{~min}$ at the rate of $12^{\circ} \mathrm{C} / \mathrm{min}$. Carrier gas was air with flow rate of $350 \mathrm{ml} / \mathrm{min}$, injector was Split 1:20 with injection volume of $3 \mu \mathrm{l}$, detector was flame ionized detector (FID) at $350^{\circ} \mathrm{C}$ (Nitrogen makeup gas at $25 \mathrm{ml} / \mathrm{min}$ ).

\section{Results}

\section{Metagenomics libraries construction}

We constructed 112,500 metagenomic libraries from the soil collected from the reed field in Shinsong-ri, Chungcheongnam-do (52,500 clones), and Mt. Jumbong in Gangwon-do (60,000 clones), Korea. This reed field have been lasted at least 100 years old, and the reed grows dense, making it a popular spot for filming. In addition, Mt. Jumbong was considered to have a high possibility of securing new genes because it is located in a remote area where human access is difficult. The constructed metagenomic library contains at least $5 \mathrm{~Gb}$ of the rhizosphere microbial genome. When randomly selected clones were digested with BamHI, they were 
identified with an average DNA insert size of approximately 35-40 kb when analyzed by agarose gel electrophoresis.

\section{Selection of gene encoding lipase Lip-1420}

Clones with lipolysis activity were selected from 112,500 plant rhizosphere metagenomic libraries. First, 46 clones with tributyrin lipolytic activity were selected. They were cleaved with BamHI restriction enzyme and double clone was removed, and 18 unique genes were successfully isolated. Lip-1420 clone was selected from 18 unique genes and Lip-1420-subclone (sub), whose size was reduced to $\sim 5 \mathrm{~kb}$ using $P s t \mathrm{I}$ restriction enzyme, was constructed. In other words, Lip-1420-sub contained the smallest DNA insert and was selected because it showed the best lipolytic activity. Sequence of Lip-1420-sub revealed that it contained 5,513 bp of DNA fragments as inserts and contained 11 or more open reading frames (ORFs). Analysis of GeneBank information revealed ORF1-4, which could be coded as a lipase enzyme. ORF1 sequence was with $48 \%$ of homology to the protein of unknown function in Thiocapsa roseopersicina and consisted of $1,590 \mathrm{bp}$ (529 amino acids). ORF2 was 50\% homologous to the LLM class flavin-dependent oxidore- ductase of Blastopirellula marina and consisted of 1,236 bp (411 amino acids). ORF3 showed 78\% homology with the esterase/lipase protein of the non-cultured organism (data from GeneBank) and was composed of 885 bp (294 amino acids). ORF4 showed 37\% homology with the alpha/beta hydrolase of Pseudorhodoplanes sinuspersici and consisted of $825 \mathrm{bp}$ (274 amino acids). ORF5 showed 26\% homology with the 3-hydroxyisobutyrylCoA hydrolase of Polistes dominula and consisted of $495 \mathrm{bp}$ (164 amino acids). Primers were prepared for transformation of these four ORFs (Table 2) and transformed into $E$. coli, respectively. However, the transformants except Lip-1420-ORF3 did not show the same lipolytic activity as Lip-1420-sub. Therefore, only Lip1420-ORF3 transformant was cultured to mass-produce lipase Lip-1420.

\section{Mass production of the new lipase Lip1420}

E. coli BL21(DE3) harboring pET21a+ORF3-6H was used to overexpress the recombinant Lip-1420 protein. The enzyme purification was performed using immobilized metal affinity chromatography using $\mathrm{Ni}$ nitrilotriacetic acid (Ni-NTA, Qiagen) (Fig. 3B). The final preparation of Lip-1420 lipase showed a major

Table 2. Primer construction for Lip-1420 gene transformation into E. coli.

\begin{tabular}{clcccc}
\hline ORF & Forward Primer & $\begin{array}{c}\text { Restriction } \\
\text { enzyme }\end{array}$ & Reverse Primer & $\begin{array}{c}\text { Restriction } \\
\text { enzyme }\end{array}$ \\
\hline ORF1 & GCGTCAGGACATATGAGATGGCTATCTGCTCT & Ndel & GCGTCAGGTCTCGAGCAGTCCCAAGAGGTTGGTC & Xhol \\
ORF2 & GCGTCAGGCCATATGAAATTCTGGATGTTTCAT & Ndel & GCGTCAGGTCTCGAGTGCGTGAGCTTCCGTCTG & Xhol \\
ORF3 & GCGACAGGCCATATGAGTCAGATTCCGGCTGA & Ndel & GCGTCAGGACTCGAGGTGTTTGAGATGTTTGTCG & Xhol \\
ORF4 & GCGACATCACATATGGCCTTACAAACCGACA & Ndel & GCACTAGCAGTCGACGCGCTTGAGAAATTGGCTGA & Sall \\
\hline
\end{tabular}
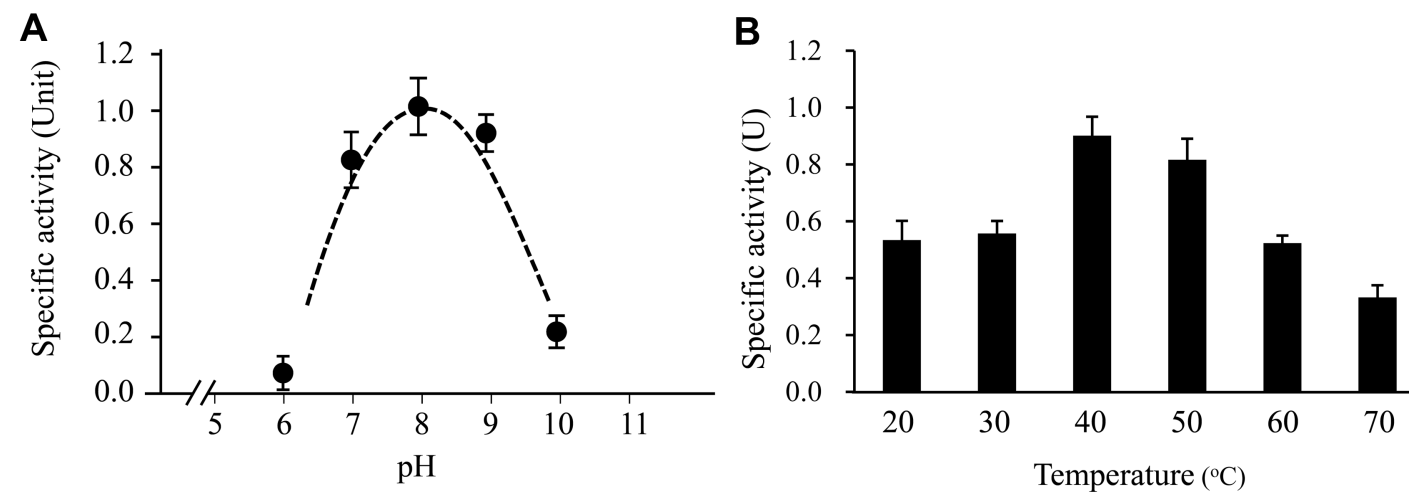

Fig. 3. Optimal condition of the enzyme activity. (A), pH; (B), temperature. The enzyme activity was assayed at $40^{\circ} \mathrm{C}$ in $50 \mathrm{mM}$ citric buffer ( $\mathrm{pH}$ 2-6.5), phosphate buffer (pH 7-9), and glycine buffer ( $\mathrm{pH} 9.5-12)$. 


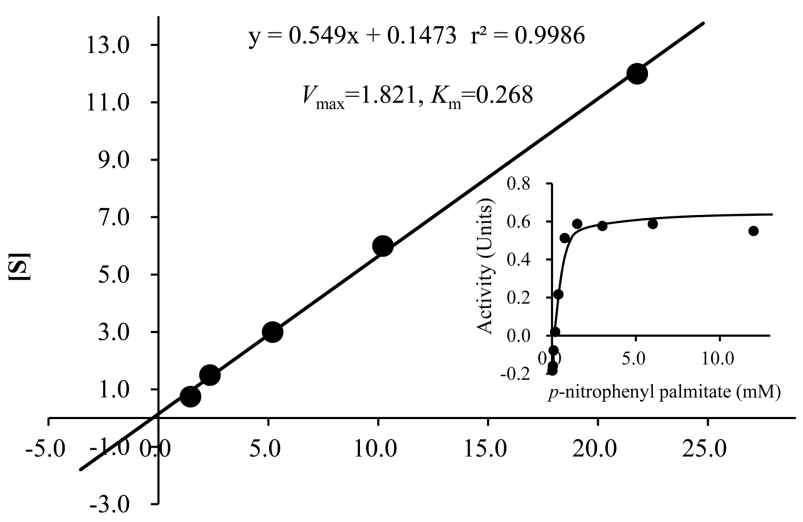

$[\mathbf{S}] / \mathbf{v}$

Fig. 4. Lineweaver-Burk double reciprocal analysis of Lip1420 lipase/esterase activity with p-nitrophenyl palmitate as the substrate. 1 unit of releasing $1 \mu \mathrm{mol}$ of free $p$-nitrophenol per minute.

single band on SDS-PAGE with a molecular weight (MW) of $33.5 \mathrm{kDa}$. Finally, $400 \mathrm{ml}(10 \mathrm{ml} \times 40 \mathrm{ml}, 1 \mathrm{mg} /$ $\mathrm{ml}$ ) of total Lip-1420 protein was collected with a BioRad FPLC system (Fig. 2A) and analyzed with SDSPAGE analysis system consisted of acrylamide gel 15\%, $1 \mathrm{~mm}$ thickness, $120 \mathrm{~V}$ constant current, $1.5 \mathrm{~h}$, Coomassie Brilliant Blue staining, and sample loading $20 \mu$ l. The final lipase production was kept in a $-70^{\circ} \mathrm{C}$ freezer at $1 \mathrm{mg} / \mathrm{ml}$ in $50 \mathrm{mM}$ Tris- $\mathrm{HCl}$ and $0.15 \mathrm{M} \mathrm{NaCl}, \mathrm{pH} 7.4$ (Fig. 2B).

\section{Lipolysis activity of the Lip-1420 lipase}

Lip-1420 lipase with a molecular weight of $33.5 \mathrm{kDa}$ was purified using affinity chromatography and enzyme characteristics were investigated. The lipolytic activity of the final purified enzyme Lip-1420 was confirmed in agar medium supplemented with the substrate tributyrin (C4). Lip-1420 showed the ability to hydrolyze triglycerides composed of short chain $\mathrm{C}_{4}$ but did not exhibit activity to degrade $\mathrm{C}_{10}, \mathrm{C}_{16}$ and $\mathrm{C}_{18}$ long chain triglycerides.

\section{Optimal conditions and kinetics}

The biochemical properties of the purified recombinant enzyme for the effective use were investigated. As a result, the optimum $\mathrm{pH}$ for the enzyme was 8.0, suggesting that it is alkalophile (Fig. 3A). The enzyme was also activated at $30-50^{\circ} \mathrm{C}$, with $40^{\circ} \mathrm{C}$ being the optimal temperature for the activity (Fig. 3B) and stable at the optimum temperature for $24 \mathrm{~h}$. At 30 or $60^{\circ} \mathrm{C}$, however, activity decreased somewhat (data not shown). The enzymatic kinetics of Lip- 1420 were performed at $40^{\circ} \mathrm{C}$ and $\mathrm{pH}$ 8.0, which were optimal conditions for substrate $p$-nitrophenyl palmitate. The $K_{\mathrm{m}}$ and $V_{\max }$ values of the protein with $p$-nitrophenyl palmitate as a substrate were $0.268 \mu \mathrm{M}$ and 75.758 units, respectively (Fig. 4). The relative enzymatic activity was gradually decreased as the chain length of the $p$-nitrophenyl ester of the fatty acid became longer.

\section{Protein structure prediction}

The biomolecular 3D structure of Lip-1420 lipase was predicted using the amino acid sequence. The expected protein secondary structure of Lip-1420 was analyzed by LOMETS (A local meta-threading-server for protein structure prediction) method. 2D structure predicted by LOMETS and 3D Modeling was carried out using the structural template identified by LOMETS in the PDB (protein data base) library. Select the following Carboxylesterase (pdb id: 3WJ1), which has the highest value among structures with normalized score of high threading alignment ( $\mathrm{Z}$ score 4.9, a normalized score of threading alignment, $\mathrm{Z}$ score $>1$ means good alignment). Unfortunately, the structural similarity with other lipases was very low [24]. The protein structure model predicted by homology modeling using the I-TASSER (a unified platform for automated protein structure and function prediction) method is shown in Fig. 8. Using SPICKER (Clustering Approach for Identifying Native Protein Folds) method [25], we have reported up to five models corresponding to the largest structural clusters based on fairness structural similarity. To estimate the reliability of each model, the highest C score (1.26) of carboxylesterase (pdb id: 3WJ1) was selected. Finally, the predicted binding site was revealed as residues $\mathrm{H} 78$, G81, D150, S151, A152, V181, and D236 according to the ligands of PAF-AH (Platelet-activating factor acetyl hydrolase, pdb id: 3D5E), which had the highest $\mathrm{C}$ score. Protein structure prediction is an effort to generate a three-dimensional model from amino acid sequences using computer algorithms of Profile-Profile threading Alignment (PPA) and Threading ASSEmbly Refinement (TASSER) program (Fig. 5).

3D model is obtained through the hierarchical protein structure modeling approach based on secondarystructure enhanced Profile-Profile threading Alignment 


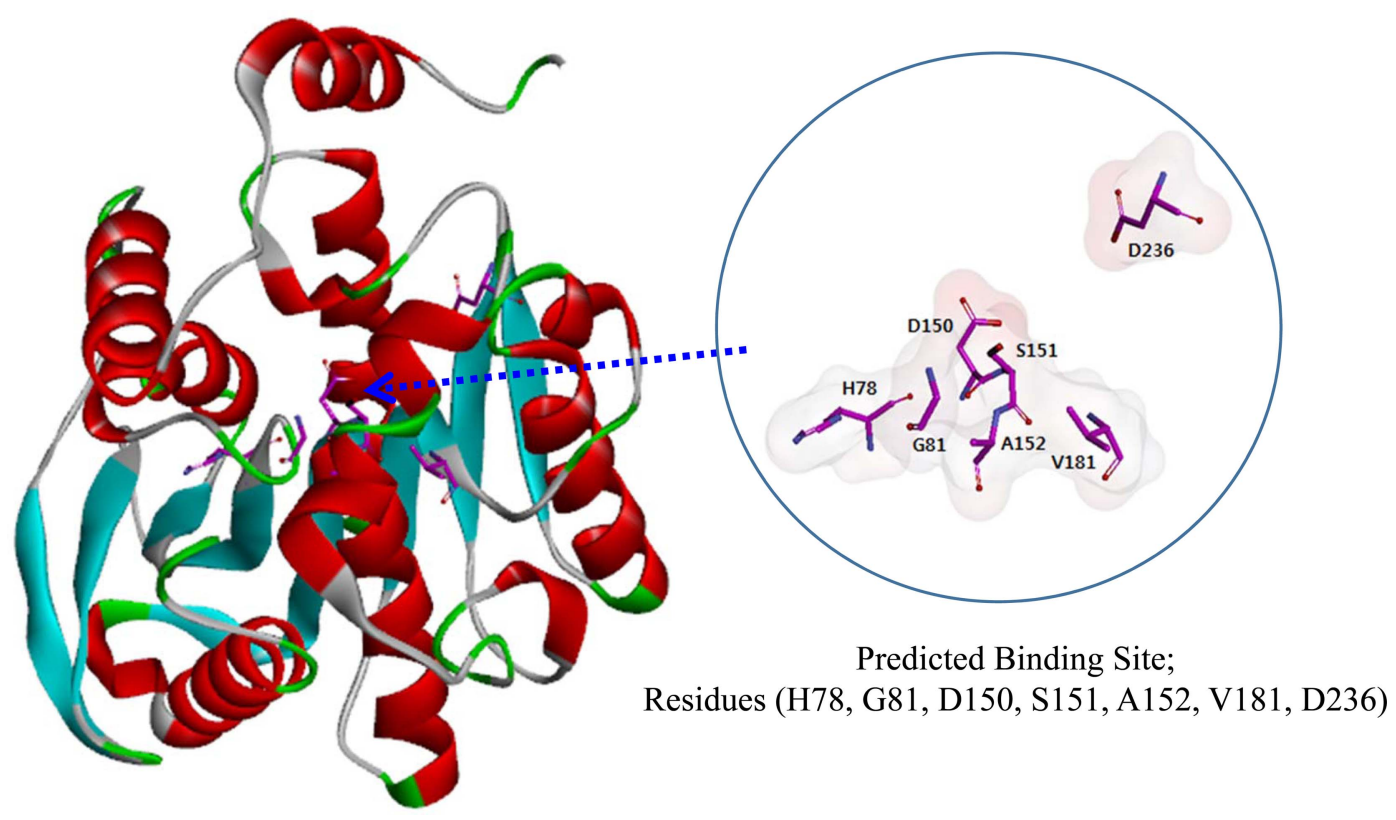

Fig. 5. 3D structure Modeling for lipase Lip-1420. Reference structure for Homology modeling : Carboxylesterase (pdb id: 3WJ1); Predicted Binding Site; Residues (H78, G81, D150, S151, A152, V181, D236). 3D model is obtained through the hierarchical protein structure modeling approach based on secondary-structure enhanced Profile-Profile threading Alignment (PPA) and the iterative implementation of the Threading ASSEmbly Refinement (TASSER) program.

(PPA) and the iterative implementation of the Threading ASSEmbly Refinement (TASSER) program.

\section{Triolein selectivity}

The Triacylglycerol, the main component of fat and oil, can be hydrolyzed into its constituent fatty acids using acids or alkalis. At this time, when alcohols are added, fatty acid alkyl esters are formed like biodiesel. An enzyme lipase can be also used instead of an acid or an alkali. However, depending on the type of enzyme, it

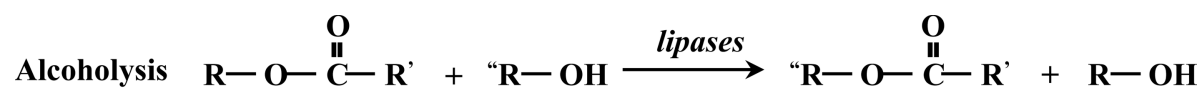

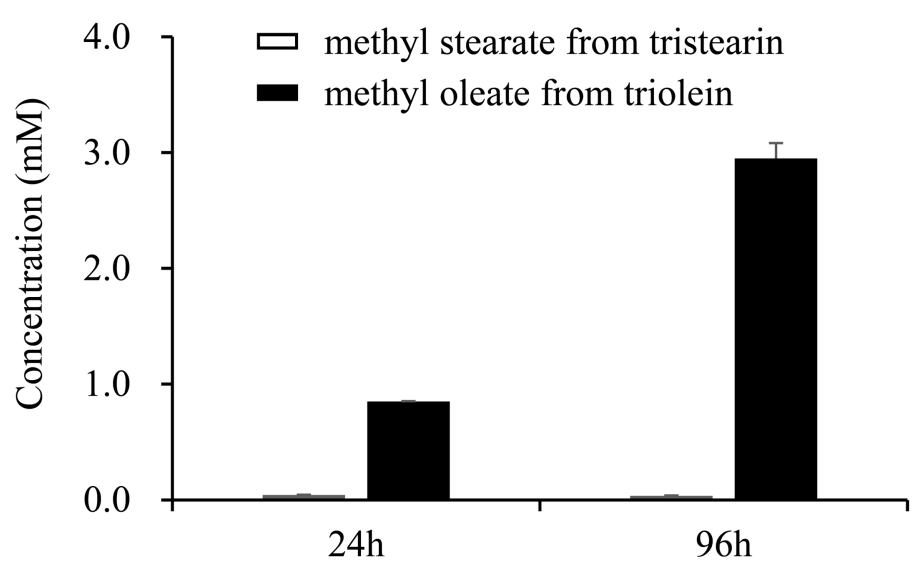

Fig. 6. Lip-1420 lipase after 24 and 96 h. Agilent Technologies $7820 \mathrm{~A}$, DB-1HT column, $30 \mathrm{~m} \times 0.32 \mathrm{~mm} \times 0.1 \mu \mathrm{m}, 40^{\circ} \mathrm{C}$ for $1 \mathrm{~min}$ hold, $40^{\circ} \mathrm{C} \rightarrow 350^{\circ} \mathrm{C}$ at $12^{\circ} \mathrm{C} / \mathrm{min}, 350^{\circ} \mathrm{C}$ for $28.167 \mathrm{~min}$ hold, temperature was held at $40^{\circ} \mathrm{C}$ for $1 \mathrm{~min}$ and then programmed to $350^{\circ} \mathrm{C}$ for $28.167 \mathrm{~min}$ at the rate of $12{ }^{\circ} \mathrm{C} / \mathrm{min}$. Air at $350 \mathrm{ml} / \mathrm{min}$, Split 1:20, $3 \mu \mathrm{l}, 350^{\circ} \mathrm{C}$. FID, $350{ }^{\circ} \mathrm{C}$ (Nitrogen makeup gas at $25 \mathrm{ml} / \mathrm{min}$ ). 
may undergo a selective esterification reaction. The enzyme Lip-1420 showed the methanolysis characteristic of producing methyl oleate from triolein composed of three 18 long chain unsaturated fatty acid oleic acids. However, it was not possible to produce methyl stearate from tristearin composed of three saturated fatty acids of 18 carbon atoms (Fig. 6). In addition, when the reaction time was increased from $24 \mathrm{~h}$ to $96 \mathrm{~h}$, methyl oleate produced from triolein continuously increased, but the methyl stearate to be formed from tristearin did not increase at all until $96 \mathrm{~h}$. Therefore, enzyme Lip-1420 was considered to have selective alcoholysis activity between triolein composed with tri-unsaturated fatty acids and tristearin composed with tri-saturated fatty acids. However, positional selectivity has not been understood yet.

\section{Discussion}

In order to use the new enzyme industrially, it is necessary to first find a new gene encoding a functional enzyme, and finally, it should be mass-produced at a low price. Researchers typically collect new variants to find new functional genes. Among the various methods, the metagenomics approach [26] can be used to find a large number of new genes and enzymes without the need for an artificial microbial culture from a variety of natural environments. In other words, if a metagenomics library with a high probability of a target gene is produced, and if a function-oriented analysis is used to find a desirable gene, it has been considered to increase the frequency of success [27]. Since lipid is the main component of plant root epidermal membranes, lipid or lipid derivatives liberated from plant root boundaries can be either nutrients or important signaling molecules to microorganisms near the root [28, 29]. Thus, metagenomic libraries made from plant rhizosphere ecosystems can be an abundant source of new lipolytic enzymes.

In this study, we constructed a metagenomic library with 112,500 clones using reed marsh soil with a history of more than 100 years and rare deep mountain soil samples. From these metagenomic libraries, 46 lipolytic clones were selected using tributyrin as a substrate and 18 unique novel lipolytic clones were isolated. Among these 18 clones, Lip-1420-subclone gene was selected and Lip-1420-sub-ORF3 was found to be a novel gene
(GenBank accession number MH628529). In conclusion, Lip-1420 was good at hydrolyzing short-chain triglyceride tributyrin but could not digest chain triglyceride longer than $\mathrm{C}_{10}$.

In general, the lipolytic activity of enzymes can be detected when fat, which is a substrate, is dissolved in water, but since $\mathrm{C}_{12}$ triglyceride is insoluble in water, it cannot be used as a substrate for lipolytic activity analysis by agar plate method without adding a surfactant. However, since $p$-nitrophenyl palmitate $\left(\mathrm{C}_{18}\right)$ can be used as a substrate for evaluating esterase activity dissolved in propanol, it was utilized as a method of investigating the biochemical properties of this enzyme.

According to general reports, lipase/esterase have characteristic $\alpha / \beta$-hydrolase folds, $\alpha$-helices and $\beta$-sheets in a definite order. Therefore, Ramnath et al. [30] classified bacterial lipolytic enzymes into 8 groups according to their amino acid sequence and biological characteristics. Among the eight families, family IV has two very conservative motifs, GXSXG and His-Gly-Gly [HGG], which play an important role in the formation of oxyanion holes [31]. This family is also known as a hormonesensitive lipase [30]. Applying Lip-1420 Lipase to these classifications belongs to Family IV. Because it has HGGG and GDSAG in the amino acid sequence.

Lipase/esterase, which is a major part of the global industrial enzyme market, is currently used in development of detergent additive, in biopolymer synthesis, in biodiesel production, in the synthesis of optically pure compounds and as food additives (remodeling of fat to develop sensory and nutritional quality) as well as in the paper industry (paper pulp removal) and as antiinflammatory agents and in cosmetics (fragrances and fragrance mixtures) and pesticides (herbicides and pesticides) and in biological purification and waste disposal [10, 32-36]. However, a large amount of edible and nonedible bio-oil is produced globally, but its value and potential have not yet been determined. For example, ethylene metathesis technology converts unsaturated fatty acids into $\mathrm{C}_{4}-\mathrm{C}_{30}$ oil fractions. These oil fragments are a chemical industry platform technology and a sustainable chemical technology that is used as a carbon dioxide abatement green chemical technology and petrochemical substitute. This platform chemistry has its own market, but it is used as a raw material for other products (polymers, surfactants, synthetic lubricants, 
plasticizers, other special chemicals, generic chemicals, biofuels, etc.). The biodegradability and biocompatibility of oil-based polymers means that you can develop a variety of high value-added functional products such as toothpaste, dandruff shampoo, melamine depigmenting cosmetics, medical and shape memory polymers. Due to the biodegradability and biocompatibility of products made from bio-oil, various functional products with high added value will be developed and the possibility of industrial application is expected to greatly expand in the near future [37].

In conclusion, a new lipase Lip-1420 was discovered using an activity-based screening method in the Korean metagenomics library. Lip-1420 is active and stable in a wide range of alkaline $\mathrm{pHs}(\mathrm{pH} 7.0$ to 9.0) and is expected to be highly applicable in the detergent industry. Since the $\mathrm{pH}$ instability of enzymes is one of the major bottlenecks for extending the range of enzyme utilization. Also, this enzyme has selective alcoholysis activity for unsaturated fatty acid oleic acid, it can be used as a raw material for sustainable chemical industry by converting unsaturated fatty acid into various oil fragments by ethylene metathesis technique.

\section{Acknowledgments}

This research was supported by a grant (NRF-2017M1A2A2049104) funded by the National Research Foundation, Ministry of Science, and Information \& Communication Technology, Republic of Korea.

\section{Conflict of Interest}

The authors have no financial conflicts of interest to declare.

\section{References}

1. Gupta R, Gupta N, Rathi P. 2004. Bacterial lipases: an overview of production, purification and biochemical properties. Appl. Mocrobiol. Biotechnol. 64: 763-781.

2. Kumar A, Dhar K, Kanwar SS, Arora PK. 2016. Lipase catalysis in organic solvents: advantages and applications. Biol. Proced. Online 18: 2 .

3. Bajaj A, Lohan P, Jha P, Mehrotra R. 2010. Biodiesel production through lipase catalyzed transesterification. J. Mol. Catal. B: Enzym. 62: 9-14.

4. Torsvik V, Goksoyr J, Daae FL. 1990. High diversity in DNA of soil bacteria. Appl. Environ. Microbiol. 56: 782-787.

5. Steele HL, Jaeger K-E, Streit DR. 2009. Advances in recovery of novel biocatalysts from metagenomes. J. Mol. Microbiol. Biotechnol. 16: 25-37.

6. Riesenfeld CS, Schloss PD, Handelsman J. 2004. Metagenomics: genomic analysis of microbial communities. Annu. Rev. Genet. 38: 525-552.

7. Ranjan R, Grover A, Kapardar RK, Sharma R. 2005. Isolation of novel lipolytic genes from uncultured bacteria of pond water. Biochem. Bioph. Res. Commun. 335: 57-65.

8. Lee MH, Hong KS, Malhotra S, Park J-H, Hwang EC, Choi HK, et al. 2010. A new esterase EstD2 isolated from plant rhizosphere soil metagenome. Appl. Microbiol. Biotechnol. 88: 1125-1134.

9. Glogauer A, Martini V, Faoro H, Couto G, Muller-Santos M, Monteiro $\mathrm{R}$, et al. 2011. Identification and characterization of a new true lipase isolated through metagenomic approach. Microb. Cell Fact. 10: 54-69.

10. Su J, Zhang F, Sun W, Karuppiah V, Zhang G, Li Z, et al. 2015. A new alkaline lipase obtained from the metagenome of marine sponge Ircinia sp. World J. Microbiol. Biotechnol. 31: 1093-1102.

11. Selvin J, Kennedy J, Lejon D, Kiran G, Dobson A. 2012. Isolation identification and biochemical characterization of a novel halotolerant lipase from the metagenome of the marine sponge Haliclona simulans. Microb. Cell Fact. 11: 72-86.

12. Wang Y, Srivastava KC, Shen G-J, Wang HY. 1995. Thermostable alkaline lipase from a newly isolated thermophilic Bacillus, strain A30-1 (ATCC 53841). J. Ferment. Bioeng. 79: 433-438.

13. Hoshino T, Sasaki T, Watanabe Y, Nagasawa T, Yamane T. 1992. Purification and some characteristics of extracellular lipase from Fusarium oxysporum f. sp. lini. Biosci. Biotechnol. Biochem. 56: 660664.

14. Hasan F, Sanh A, Hameed A. 2005. Industrial applications of microbial lipases. Enzyme Microb. Technol. 39: 235-251.

15. Ochoa LC, Gomez CR, Alfaro GV, Ros R. 2005. Screening, purification and characterization of the thermoalkalophilic lipase produced by bacillus thermoleovorans CCR11. Enzyme Microb. Technol. 37: 648-654.

16. Ericks SA, Rita CR. 2008. Transesterification activity of a novel lipase from acinetobacter venetianus RAG-1. Antonie Van Leeuwenhoek. 94: 621-625.

17. Rondon MR, August PR, Bettermann AD, Brady SF, Grossman TH, Liles MR, et al. 2000. Cloning the soil metagenome: a strategy for accessing the genetic and functional diversity of uncultured microorganisms. Appl. Environ. Microbiol. 66: 2541-2547.

18. Lee SW, Won K, Lim HK, Kim JC, Choi GJ, Cho KY. 2004. Screening for novel lipolytic enzymes from uncultured soil microorganisms. Appl. Microbiol. Biotechnol. 65: 720-726.

19. Vieira J, Messing J. 1987. Production of single-stranded plasmid DNA. Methods Enzymol. 153: 3-11.

20. Sambrook J, Fritsch EF, Maniatis T. 1989. Molecular cloning. A laboratory manual, pp 1549. 2nd ed. Cold Spring Harbor Laboratory Press, New York.

21. Laemmli UK. 1970. Cleavage of structural proteins during the assembly of the head of bacteriophage T4. Nature 227: 680-685.

22. Wu S, Zhang Y. 2007. LOMETS: a local meta-threading-server for 
protein structure prediction. Nucleic Acids Res. 35: 3375-3382.

23. Roy A, Kucukural A, Zhang Y. 2010. I-TASSER: a unified platform for automated protein structure and function prediction. Nat. Protoc. 5: 725-738.

24. Ngo TD, Ryu BH, Ju H, Jang E, Park K, Kim KK, et al. 2013. Structural and functional analyses of a bacterial homologue of hormonesensitive lipase from a metagenomics library. Acta Crystallogr. $D$ Biol. Crystallogr. 69: 1726-1737.

25. Zhang Y, Skolnick J. 2004. SPICKER: a clustering approach to identify near-native protein folds. J. Comput. Chem. 25: 865-871.

26. Handelsman J. 2004. Metagenomics: application of genomics to uncultured microorganisms. Microbiol. Mol. Biol. Rev. 68: 669-685.

27. Simon C, Daniel R. 2009. Achievements and new knowledge unraveled by metagenomic approaches. Appl. Microbiol. Biotechnol. 85: $265-276$.

28. Sandkvist M. 2001. Biology of type II secretion. Mol. Microbiol. 40: 271-283.

29. Wang X. 2004. Lipid signaling. Curr. Opin. Plant Biol. 7: 329-336.

30. Ramnath L, Sithole B, Govinden R. 2017. Classification of lipolytic enzymes and their biotechnological applications in the pulping industry. Can. J. Microbiol. 63: 179-192.
31. Mohamed YM, Ghazy MA, Sayed A, Ouf A, El-Dorry H, Siam R. 2013. Isolation and characterization of a heavy metal-resistant, thermophilic esterase from a Red Sea brine pool. Sci. Rep. 3: 3358-3366.

32. Haki GD, Rakshit SK. 2003. Developments in industrially important thermostable enzymes: a review. Bioresour. Technol. 89: 17-34.

33. Joseph B, Ramteke PW, Thomas G, Shrivastava N. 2007. Standard review cold-active microbial lipases: a versatile toosul for industrial applications. Biotechnol. Mol. Biol. Rev. 2: 39-48.

34. Cherif S, Mnif S, Hadrich F, Abdelkafi S, Sayadi S. 2011. A newly high alkaline lipase: an ideal choice for application in detergent formulations. Lipids Health Dis. 10: 221-229.

35. Lailaja VP, Chandrasekaran M. 2013. Detergent compatible alkaline lipase produced by marine Bacillus smithii BTMS 11. World J. Microbiol. Biotechnol. 29: 1349-1360.

36. López-López O, Cerdán ME, Siso MIG. 2014. New extremophilic lipases and esterases from metagenomics. Curr. Protein Pept. Sci. 15: 445-455.

37. Jeon JY, Han Y, Kim Y-W, Lee Y-W, Hong S, Hwang IT. 2019. Feasibility of unsaturated fatty acid feedstocks as green alternatives in bio-oil refinery. Biofuels Bioprod. Biorefin. 13: 690-722. 